\title{
Development of an Energy-Use Estimation Methodology for the Revised Navy Manual MO-303
}

\author{
E.E. Richman \\ J.M. Keller \\ A.G. Wood \\ A.L. Dittmer
}

January 1995

Prepared for

the U.S. Navy

under a Related Services Agreement

with the U.S. Department of Energy

under Contract DE-AC06-76RLO 1830

Pacific Northwest Laboratory

Richland, Washington 99352 



\section{DISCLAIMER}

This report was prepared as an account of work sponsored by an agency of the United States Government. Neither the United States Government nor any agency thereof, nor any of their employees, make any warranty, express or implied, or assumes any legal liability or responsibility for the accuracy, completeness, or usefulness of any information, apparatus, product, or process disclosed, or represents that its use would not infringe privately owned rights. Reference herein to any specific commercial product, process, or service by trade name, trademark, manufacturer, or otherwise does not necessarily constitute or imply its endorsement, recommendation, or favoring by the United States Government or any agency thereof. The views and opinions of authors expressed herein do not necessarily state or reflect those of the United States Government or any agency thereof. 


\section{DISCLAIMER}

Portions of this document may be illegible in electronic image products. Images are produced from the best available original document. 


\section{Summary}

The U.S. Navy commissioned Pacific Northwest Laboratory (PNL) to revise and/or update the Navy Utilities Targets Manual, NAVFAC MO-303 (U.S. Navy 1972b). The purpose of the project was to produce a current, applicable, and easy-to-use version of the manual for use by energy and facility engineers and staff at all Navy Public Works Centers (PWCs), Public Works Departments (PWDs), Engineering Field Divisions (EFDs), and other related organizations.

The revision of the MO-303 manual involved developing a methodology for estimating energy consumption in buildings and ships. This methodology can account for, and equitably allocate, energy consumption within Navy installations. The analyses used to develop this methodology included developing end-use intensities (EUIs) from a vast collection of Navy base metering and billing data. A statistical analysis of the metering data, weather data, and building energy-use characteristics was used to develop appropriate EUI values for use at all Navy bases. A complete Navy base energy reconciliation process was also created for use in allocating all known energy consumption.

Initial attempts to use total Navy base consumption values did not produce usable results. A parallel effort using individual building consumption data provided an estimating method that incorporated weather effects. This method produced a set of building EUI values and weather adjustments for use in estimating building energy use. A method of reconciling total site energy consumption was developed based on a "zero-sum" principle. This method provides a way to account for all energy use and apportion part or all of it to buildings and other energy uses when actual consumption is not known. The entire text of the manual was also revised to present a more easily read, understood, and usable document. 



\section{Contents}

Summary $\ldots \ldots \ldots \ldots \ldots \ldots \ldots \ldots \ldots \ldots \ldots \ldots \ldots \ldots \ldots \ldots \ldots \ldots$

1.0 Introduction $\ldots \ldots \ldots \ldots \ldots \ldots \ldots \ldots \ldots \ldots \ldots \ldots \ldots \ldots \ldots \ldots$

2.0 Methodology Revision $\ldots \ldots \ldots \ldots \ldots \ldots \ldots \ldots \ldots \ldots \ldots \ldots \ldots$

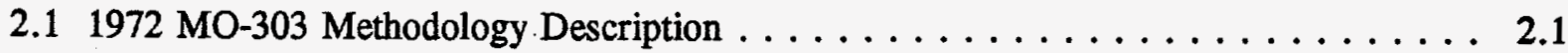

2.2 Revised MO-303 Methodology Description . . . . . . . . . . . . 2.1

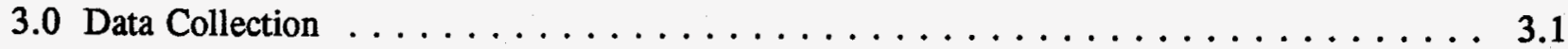

3.1 Building/Area Metered Data $\ldots \ldots \ldots \ldots \ldots \ldots \ldots \ldots \ldots \ldots \ldots \ldots$

3.2 Installation-Level Data $\ldots \ldots \ldots \ldots \ldots \ldots \ldots \ldots \ldots \ldots \ldots \ldots \ldots \ldots \ldots \ldots$

4.0 Building EUI Development $\ldots \ldots \ldots \ldots \ldots \ldots \ldots \ldots \ldots \ldots \ldots \ldots$

4.1 Multiple-Regression Analysis of Installation Billing Data $\ldots \ldots \ldots \ldots \ldots . \ldots$

4.1.1 Estimating Total Installation EUI $\ldots \ldots \ldots \ldots \ldots \ldots \ldots \ldots \ldots$

4.1 .2 Estimating Building Type EUI $\ldots \ldots \ldots \ldots \ldots \ldots \ldots \ldots \ldots \ldots$

4.2 Linear-Regression Analysis of Metered Data $\ldots \ldots \ldots \ldots \ldots \ldots$

5.0 Ship Energy-Use Estimation Development $\ldots \ldots \ldots \ldots \ldots \ldots \ldots$

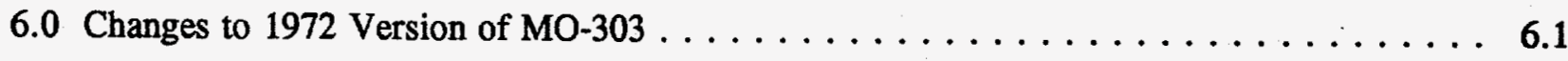

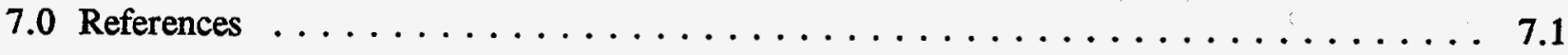




\section{Figures}

4.1 Linear Regression Used to Calculate Electric EUI Equation for Building Type ADMIN . . 4.8

4.2 Linear Regression Used to Calculate Electric EUI Equation for Building Type ELEC . . . . 4.9

\section{Tables}

4.1 Family Housing Electricity Model Results $\ldots \ldots \ldots \ldots \ldots$

4.2 Family Housing Fossil Fuel Model Results $\ldots \ldots \ldots \ldots \ldots$

4.3 Commercial Building Electricity Model Results $\ldots \ldots \ldots \ldots$

4.4 Commercial Building Fossil Fuel Model Results $\ldots \ldots \ldots \ldots \ldots \ldots$

4.5 Comparison of Billed and Calculated Energy Consumption at Navy Installations $\ldots \ldots$. . 4.11

4.6 Comparison of Billed and Calculated Building-Only Energy Consumption $\ldots \ldots \ldots .12$

4.7 Results of the Linear-Regression Calculations . . . . . . . . . . . . . 4.13 


\subsection{Introduction}

The Navy Utilities Targets Manual, NAVFAC MO-303, is a guide to Navy facility engineers and energy managers (U.S. Navy 1972b). The manual was originally written to provide "...procedures for estimating quantities and costs for optimum utilities operation and maintenance and for comparing these with actual usage and expenditures." The 1972 version of MO-303 refers to optimum values as "targets" and generally derives these values from energy consumption allowances for a facility's various energy-consuming equipment and characteristics. The manual has been primarily used as a guide to estimate current actual energy consumption rather than targeted consumption. Other programs and efforts aimed at improved energy efficiency at Navy facilities have been used to determine potential efficiency improvements instead of using the manual to develop targets.

The U.S. Navy commissioned Pacific Northwest Laboratory (PNL) ${ }^{(a)}$ to revise and/or update the 1972 MO-303 manual. This task included developing an analysis methodology for estimating energy consumption. The results of this effort are intended to produce a current, applicable, and easy-to-use version of the manual. The manual is intended for use by energy and facility engineers and staff at all Navy Public Works Centers (PWCs), Public Works Departments (PWDs), Engineering Field Divisions (EFDs), and other related organizations. This manual revision is a guide to help estimate current and future energy consumption for facilities and ships. The revision includes a methodology to account for, and equitably allocate, energy consumption within Navy installations.

The procedure used by PNL to develop the methodology for estimating energy consumption is described in this report. Section 2.0 of this report discusses the revised methodology for estimating and reconciling energy use. The data collection process used by PNL is discussed in Section 3.0. Section 4.0 describes the development of end-use intensities (EUIs) and other metrics. Section 5.0 discusses the development of a method for estimating ship energy use. A list of changes to the 1972 version of MO-303 is provided in Section 6.0. Section 7.0 provides a list of publications referenced in this report.

(a) PNL is a multiprogram laboratory operated for the U.S. Department of Energy by Battelle Memorial Institute under Contact DE-AC06-76RLO 1830. 


\subsection{Methodology Revision}

\subsection{MO-303 Methodology Description}

The 1972 version of MO-303 includes a classical component modeling methodology to estimate expected energy use by buildings and ships (U.S. Navy 1972b). The manual assesses all primary pieces of equipment and facility characteristics such as construction component areas and infiltration levels. Detailed calculations that include sound engineering principles are used to derive consumption values for each component. Component values are adjusted for weather, hours of use, and other estimated or derived operational factors. A sum of these component values is the "target" value for that facility.

While this method is based on sound principles, it is a modeling estimate that cannot account for all operational and physical characteristics of a facility. Historically, modeling a facility's operational characteristics has been extremely difficult because of the wide variability and unpredictability of operational effects. This modeling methodology also requires a lot of detailed input data for each facility to use the detailed estimation principles and calculations. The system does not provide any way to reconcile these estimates based on actual consumption at an installation or other large area. Without a reconciliation, the sum of estimated facility consumption may not equal the actual total energy consumption for the installation.

Many users apply the manual's estimation principles and calculations that are supported with available or gathered data and incorporate other methods to arrive at individual facility estimates. The users then apply various simple or well-developed methods to reconcile the facility estimates to derive appropriate and equitable energy allocations between the facilities and other energy uses at their installation.

\subsection{Revised MO-303 Methodology Description}

The primary purpose of this manual revision is to create an easy-to-use revised methodology for estimating and reconciling energy use. This methodology should produce reasonably accurate, repeatable, and defendable estimates with minimum required data collection.

The revised methodology is primarily based on the application of EUI values (expressed in energy per square foot per year) for buildings and energy load values for ships. These energy consumption metrics are used to help estimate energy consumption for facilities and ships with nonmetered or unknown energy consumption. The user chooses appropriate values for each facility or ship based on user knowledge or other installation data. The values can be further adjusted to represent installation-specific characteristics. The user can then estimate facility or ship energy use by applying the appropriate value to facility square footage or ship utility connect hours. 
Other energy-use estimates for nonbuilding and nonship use, such as water and sewer systems, street lighting, and line losses, are derived based on available installation data. The manual provides calculation assistance, based on simplified methodologies using readily available installation data, for these types of energy use.

After making all energy-use estimates, a reconciliation of the total installation energy consumption can be completed. The reconciliation process incorporated in the revised MO-303 was developed based on similar processes used in energy-use analyses of other military installations. The process involves accounting for all energy use representing a utility bill or other total installation energy consumption value. This process begins by subtracting all known (metered) consumption. Related energy-use estimates (where an accurate estimate is obtainable) are also subtracted such as line losses, water system power, street lights, and energy transfers. The remaining energy use is nonmetered or unaccounted for use from ships, buildings, or other areas. Because estimates for this energy use were made using the same general process, assumptions, and defaults that are based on real data inputs, they can be considered proportionally related to each other in terms of estimated energy use. Remaining energy use can therefore be apportioned among nonmetered or other unaccounted for uses relative to total estimated use. While this process cannot produce exact and actual values, the values can be considered reasonable and equitable estimates in place of metered data. This is particularly true when the remaining consumption is within $20 \%$ of the total estimated consumption. When these values differ by more than $20 \%$, a thorough check of all other inputs and calculations should be made to ensure no errors or missed items exist. 


\subsection{Data Collection}

The first step in developing energy-use values and appropriate methodologies was to collect as much metered and other energy consumption data as possible. To collect required data we drafted letters requesting metered data as well as other energy-related data such as plant production and characteristics, ship and facility occupation, and weather data. A letter from the Navy project contact to each of the installation contacts was attached to each PNL letter to ensure no questions existed concerning the release of data to PNL. Originally, we sent 39 letters to energy-related contacts at Navy installations. We also called the contacts to ensure that the letters were received and understood. Later in the project, we faxed an additional 43 letters to other contacts (not specifically energy related) to collect additional data. Other sources of energy-related data were also obtained for all installations. These sources included Navy-wide Real Property Listings (RPLs) (U.S. Navy 1992; U.S. Navy 1993b), Utilities Analysis Reports (UPA), Defense Energy Information System (DEIS) reports, and 30-year weather data (U.S. Navy 1978) for available locations. Other supplementary data included various reports and manuals related to energy use (Dixon et al. 1992; Dixon et al. 1993; Halverson et al. 1993; Keller et al. 1993a; Keller et al. 1993b; Richman et al. 1994; Secrest et al. 1991; U.S. Navy 1972a; U.S. Navy 1991) or data referenced in the 1972 version of MO-303 (U.S. Navy 1972b).

\subsection{Building/Area Metered Data}

Installations provided building and area metered data in paper and/or electronic form. The data often represented old or neglected metering points with questionable data values. When received, building and area metered data were added to a large, standard format metered data summary spreadsheet. We removed any data with installation-identified erroneous readings or gross inconsistencies from the analysis spreadsheet. Each building associated with metered data was found in the RPL by building number and unit identification code (UIC). The building type and square footage from the RPL were added to the metered data summary for each building. Metered electric data were converted to kilowatt-hours per year $(\mathrm{kWh} / \mathrm{yr})$ and fossil fuel data were converted to thousand British thermal units per year ( $\mathrm{kBtu} / \mathrm{yr})$. An attempt was made to determine the fuel types used for each end use in the metered buildings. A wide range of possible combinations of heating and cooling energy types exists, all of which affect the EUI.

In a separate database, we cross-referenced every UIC installation code in the RPL to the nearest city and state with available weather data. Heating degree-days base $65^{\circ} \mathrm{F}$ [HDD(65)], cooling degree-days base $65^{\circ} \mathrm{F}$ [CDD(65)], and wet-bulb hours greater than $73^{\circ} \mathrm{F}$ [WBH(73)] were found and added to the database. We then assigned the weather data by UIC to each building with metered data.

Reserve centers or other small installations often consist of a few buildings, sometimes with only one building type. We searched the total RPL for any UICs with three or less building types. For these small installations, the DEIS/UPA installation-level data were assumed to be compatible with the individual metered data because few building types existed. For each installation, the DEIS/UPA data 
were checked to determine if total installation billing data were available. If billing data were available, they were prorated to the building types by square footage. These data points were added to the metered data spreadsheet. Most building types contained in this data were administrative, training, and shop buildings.

\subsection{Installation-Level Data}

The two installation-level sources of metered data were DEIS and UPA. The DEIS data is the standard format used by all Navy installations to report energy consumption. This source reports energy use by fuel type for 19 different fuel types. Most of the energy used is electricity, natural gas, and fuel oil. Large installations are often divided into shore facilities, family housing, ships, simulators, transmitters, miscellaneous, and cogeneration. Energy use is reported in million British thermal units (MBtus) per year. This data has generally been useful for accounting purposes but NOT for estimating energy in this analysis because of the categorization and reporting formats. Therefore, we used this data sparingly.

The Naval Facilities Engineering Command, Atlantic Division (LANTNAVFACENGCOM), collects UPA data. UPA data consists of a database containing information gathered from actual utility bills sent in from each installation. The data is limited to metered utilities-usually electricity and natural gas. The data were sorted by UIC and compared to the DEIS data. Significant differences in the data usually existed. (It was outside the scope of the project to determine the reasons for discrepancies.) Because the UPA data came from actual utility bills, they were used wherever available in place of the DEIS data. We used the DEIS data to prorate the UPA data by use area (e.g., shore facilities, family housing)

To separate family housing energy use, we calculated the percentage of DEIS energy use assigned to family housing using the combined DEIS/UPA data (for those UICs where energy use was reported separately). Energy use for family housing was then determined by multiplying by the UPA energy consumption. The floor area of all family housing was also summed by UIC for these same locations. The combined data were also used to get energy consumption for those UICs where three or less building types were reported in the RPL. 


\subsection{Building EUI Development}

The analysis performed for the MO-303 revision primarily provided a set of EUI values applicable to Navy buildings. The development of these values was based on similar EUI development work completed for several other military installations under other DOE contracts. This process used the same principles but relied exclusively on Navy installation data.

An analysis of available data was performed using two different approaches. Initially, these two approaches were expected to produce similar results that could be compared to derive appropriate building energy-use values.

The first approach was a statistical multiple-regression analysis on installation-wide data. This method used the nearly complete set of total installation energy and facility characteristics data. Unfortunately, the results of this analysis were inconclusive and thus were not used as part of the final MO-303 revision. A description of the procedure and results of this method are presented for complete documentation. These results provide insight into the vast variability of available data and the problems associated with attempting to derive accurate specific building values from the data.

The second approach was a more intuitive method that used limited individual facility metered data and applied linear-regression analysis methods to metered facility type data. This method produced estimated EUIs that compared reasonably well to expected and otherwise documented values. These EUIs are used in the revised MO-303.

\subsection{Multiple-Regression Analysis of Installation Billing Data}

The multiple-regression analysis method used installation-level data to determine building type EUIs for each installation and appropriate installation weather adjustments. The data included total annual energy consumption, building square footage by type, and annual weather indicators of heating, cooling, and wet bulb. The first step in this analysis was to determine installation data points that would be useful in deriving specific building type EUI values. Thus, a total installation EUI value was determined from the data for each installation. This value was used to identify those installations with unreasonable energy per square foot values. The final step in the analysis was to apply a similar methodology to the installation data and building type square footages to refine specific building type EUI values.

\subsubsection{Estimating Total Installation EUI}

Base energy consumption is defined as consumption that is independent of weather. In this analysis, base energy consumption is a function of building type because no other information exists such as vintage or end use. 
The data were initially separated by fuel type (electricity and fossil fuel) and building sector (commercial and residential). We ran a regression analysis on each of these data sets independently. Because most installations use both electricity and fossil fuel, the installations were characterized as being fossil-fueled, electric-fueled, or both. To supplement the annual weather indicators, we also characterized each installation by a weather bin corresponding to the bins defined for use in the FEDS software (FEMP 1993). Given total installation energy consumption and building square footage, the base energy model is

$$
\text { Energy }_{\text {base }}=\sum_{i \text { in }}^{\text {bype }} \text { Energy }_{i}
$$

where Energy $\mathrm{i}_{\mathrm{i}}=$ the energy consumption for each building type.

The weather adjustment is presented as a scaling factor for the installation EUI and is assumed to be a linear combination of the weather predictors. By calling the weather factor $\mathrm{W}$, the total installation energy model (including weather adjustment) is

$$
\text { Energy }_{\text {toot }}=W\left(\sum_{i \text { in }}^{\text {bype }} \text { Energy }\right)
$$

The weather factor $\mathrm{W}$ is determined by examining how the weather-dependant portion of the EUI (specified by the linear model error) responds to weather variables or bins. Note that the weather adjustment approach, which is a linear combination of heating, cooling, and humidity indicators, is only appropriate for annual data. This approach is not appropriate for monthly data because the heating and cooling effects are distinct and do not change by month (or season) and are based predominantly on the indicator reflecting the weather-dependant use (heating or cooling).

Installation EUI values developed in this stage of the analysis had a wide variance mainly because of the nature of the installation-level data. Installation total energy values include various combinations of process-type facilities, as well as the typical facilities found on Navy installations. The values also include nonbuilding energy use such as pumping and street lights. By removing data for installations obviously dominated by nonbuilding energy use, a somewhat consistent set of data points could be used in developing EUI values. All of these EUI values would include some portion of nonbuilding use in modest amounts. If the nonbuilding amounts could be considered similar (outliers removed), then building EUI values could be derived by prorating all EUIs.

We identified statistical outliers by creating a model of the data and visually inspecting the partial residual errors for outliers. Equation (4.1) was used for the initial model because early results showed little response to weather. Removing outliers generally doubled the accuracy of the models, but some of the estimated coefficients were still significantly different than expected. A filter of the total installation values was also applied to further refine the estimates. Installations with extremely 
high total energy-use values were eliminated from further analysis because their energy use was probably dominated by nonbuilding consumption.

We applied a second filtering process to the data. This process matched the estimated total installation EUI with an expected range of total installation EUIs. These expected total installation EUIs were derived from the mix of building types and square footages present at each installation and the associated estimated building type EUIs. If the installation EUI was far out of the expected range, it was assumed to be invalid. Expected electricity and fossil fuel commercial and residential EUI values from previous military assessment analyses were used in this filtering process. Installations with very high EUIs were dominated by nonbuilding loads and excluded from further analysis. Installations with very low EUIs were not representative of normally operating installations and thus were also removed from further analysis.

In applying the weather-dependant model [Equation (4.2)], we found that the weather-dependant portion of the annual installation EUI was very weak. Therefore, we did not further estimate this effect. This observation is consistent with the fact that the weather-dependant portion of the EUI will vary from month to month, while the building-dependant portion is relatively constant year-round. A weather response was not expected in annual consumption data.

\subsubsection{Estimating Building Type EUI}

By normalizing Equations (4.1) and (4.2) by square footage, we get a function in terms of building type EUI and fraction of installation floor space.

$$
\mathrm{EUI}_{\text {base }}=\sum_{\mathrm{i} \text { in }}^{\text {bype }} \frac{\text { floor }_{\mathrm{i}}}{\text { floor }_{\text {toolal }}} \mathrm{EUI}_{\mathrm{i}}
$$

and

$$
\text { EUI }_{\text {tooal }}=\mathrm{W}\left(\sum_{\mathrm{i} \text { in }}^{\text {bype }} \frac{\text { floor }_{\mathrm{i}}}{\text { floor }_{\text {lotal }}} \text { EUI }_{\mathrm{i}}\right)
$$

where

$$
\begin{aligned}
\text { EUI }_{\text {base }} & =\text { total installation EUI without weather effects } \\
\text { EUI }_{\text {total }}= & \text { total installation EUI with weather effects } \\
\text { floor }_{\mathrm{i}} / \text { floor }_{\text {toal }}= & \text { percent of floor area for each building type } \\
\text { EUI }_{\mathrm{i}} & =\text { building type energy-use coefficient estimated by the linear part of the } \\
& \text { regression model. }
\end{aligned}
$$

We normalized the good installation-level data by installation total square footage to implement models of Equations (4.3) and (4.4). This normalization transformed the installation total square footage to the fraction of floor space of that building type (known) and transformed the building type energy to the building type EUI (unknown). A linear-regression model was used to estimate the unknown EUI . 
To estimate the unknown EUI, we first applied the base energy model defined by Equation (4.3). The initial estimated building EUI coefficients were extremely variable. We investigated eliminating or combining some of the building types to get better estimates for the building types that were well represented. We tried removing or combining commercial building types to get better estimates in the electric commercial building data set. Strategically removing under represented or skewed building types should improve the signal of the remaining building types. This approach is a sound way to get a tighter fit in the model, but it did not work with this data. Combining building types did not work well perhaps because of the variability of the data. Because the housing data sets poorly represented the detached family housing type, we initially removed this housing type from the housing models without trying to combine it with another type. As a result, the general fit of the model improved, but the estimates for the remaining building types became less stable. Therefore, the detached family housing group was kept in the model.

Next, we explored the weather-dependant model defined by Equation (4.4). Because the statistical analysis of a generalized linear model like Equation (4.4) is complex, we attempted to split the EUI into its building type-dependant and weather-dependant components. The weatherindependent (base) EUI is estimated by assigning each installation to an appropriate weather bin and independently modeling each bin by Equation (4.3). Because each bin has the same weather characteristics, the EUI estimates are weather-independent. Because we assume that the building type component of the EUI is independent of weather, the EUI estimates for each building type should be fairly uniform across weather bin models. However, in our analysis a large variance existed between the EUI estimates for the different weather bins. This large variance may have resulted from a lack of broad base data for all building types in each weather bin.

We applied filters to both building level models to identify outlying building type EUI values. Minimum and maximum criteria were established for each building type. In some cases, these criteria could not be applied because they would eliminate most or all of a sample. The regression model analysis results for family housing electricity use are presented in Table 4.1. The maximum EUI criterion was not applied to this set because it eliminated most of the sample. Although the minimum criterion improved the general fit, it reduced the sample size so that no improvement was seen in the estimate of parameters. The estimate for detached family housing is very weak because of it's small contribution to the data set. Thus, the estimate should only be presented as an average with a wide confidence interval. All other estimates are statistically significant.

The analysis results for family housing fossil fuel use are presented in Table 4.2. Half of this data set was removed by the extreme value criteria, resulting in a $50 \%$ improvement in the overall fit. The estimate for detached family housing is very weak because of its small contribution to the data set. Thus, the estimate should be presented only as an average with a wide confidence interval. All other estimates are statistically significant.

Analysis results for commercial building electricity use are presented in Table 4.3. The extreme value criteria eliminated about 100 installations but improved the overall performance of the model. Estimates with a Pr less than 0.5 are generally statistically significant given the variability of this data 
Table 4.1. Family Housing Electricity Model Results

\begin{tabular}{|l|c|c|c|c|}
\hline & $\begin{array}{c}\text { EUI Value, } \\
\mathrm{kWh} / \mathrm{ft}^{2}-\mathrm{yr}\end{array}$ & Standard Error & $\mathrm{t}$ Value & $\operatorname{Pr}(>|\mathrm{t}|)$ \\
\hline \hline Duplex & 10.440 & 1.929 & 5.413 & 0.000 \\
\hline Multi & 8.104 & 0.986 & 8.223 & 0.000 \\
\hline Attached & 14.819 & 2.042 & 7.257 & 0.000 \\
\hline Detached & 5.501 & 107.535 & 0.051 & 0.959 \\
\hline \hline $\begin{array}{l}\text { Residual standard error: } 5.89 \text { on } 101 \text { degrees of freedom. } \\
\text { Multiple R-squared: } 0.7538 . \\
\text { F-statistic: } 77.3 \text { on 4 and } 101 \text { degrees of freedom; the p-value is } 0 .\end{array}$ \\
\hline
\end{tabular}

Table 4.2. Family Housing Fossil Fuel Model Results

\begin{tabular}{|l|c|c|c|c|}
\hline & $\begin{array}{c}\text { EUI Value, } \\
\text { Btu/ } \mathrm{ft}^{2}-\mathrm{yr}\end{array}$ & Standard Error & $\mathrm{t}$ Value & $\operatorname{Pr}(>|\mathrm{t}|)$ \\
\hline Duplex & 0.115 & 0.019 & 6.183 & 0.0 \\
\hline Multi & 0.092 & 0.009 & 10.792 & 0.0 \\
\hline Attached & 0.071 & 0.014 & 4.901 & 0.0 \\
\hline Detached & 0.432 & 0.635 & 0.682 & 0.5 \\
\hline $\begin{array}{l}\text { Residual standard error: } 0.03008 \text { on } 35 \text { degrees of freedom. } \\
\text { Multiple R-squared: } 0.9138 \text {. } \\
\text { F-statistic: } 92.72 \text { on 4 and 35 degrees of freedom; the p-value is 0. }\end{array}$ \\
\hline
\end{tabular}

set. Less significant estimates should be viewed as averages with wide confidence intervals. Negative coefficients indicate the statistical error of the model and may imply that some of the erroneous data were not captured by the extreme value filter. Note the high estimate for CHAPEL. CHAPEL and LAUNDRY were under represented in the data, accounting for only $0.4 \%$ of the floor space. GRO accounted for only $0.8 \%$ of the floor space. The analysis results for commercial building fossil fuel use are presented in Table 4.4. The extreme value criteria eliminated over half of this data set but improved the overall performance of the model.

The family housing models all present positive building EUI estimates. However, an extremely wide range of estimates exists between housing types. The values are considered too far apart to be reliable. A wide range of estimates also exists between commercial building EUIs with negative values. These values are also considered too variable to be reliable energy-use estimates. A proration of these estimates to remove nonbuilding energy effects would not improve the variability. 
Table 4.3. Commercial Building Electricity Model Results

\begin{tabular}{|c|c|c|c|c|}
\hline & $\begin{array}{l}\text { EUI Value, } \\
\mathrm{kWh} / \mathrm{ft}^{2}-\mathrm{yr}\end{array}$ & Standard Error & t Value & $\operatorname{Pr}(>|t|)$ \\
\hline ADMIN & 11.623 & 3.695 & 3.146 & 0.002 \\
\hline BRK & 10.682 & 5.021 & 2.127 & 0.035 \\
\hline CHAPEL & 168.098 & 184.827 & 0.909 & 0.364 \\
\hline CLINIC & 26.790 & 54.615 & 0.491 & 0.624 \\
\hline CLUB & -23.602 & 38.163 & -0.618 & 0.537 \\
\hline DGR & 33.937 & 24.515 & 1.384 & 0.168 \\
\hline DINING & 26.488 & 37.962 & 0.698 & 0.486 \\
\hline ELEC & 40.506 & 19.333 & 2.095 & 0.037 \\
\hline GRO & 36.656 & 46.184 & 0.794 & 0.428 \\
\hline HANGAR & 13.714 & 5.708 & 2.403 & 0.017 \\
\hline HOSP & 41.760 & 2.397 & 17.422 & 0.000 \\
\hline HOTEL & 18.050 & 7.125 & 2.534 & 0.012 \\
\hline LAB & 28.209 & 2.482 & 11.365 & 0.000 \\
\hline LAUNDRY & -4.621 & 282.415 & -0.016 & 0.987 \\
\hline MWR & 21.129 & 26.430 & 0.799 & 0.425 \\
\hline OTHER & 11.817 & 16.189 & 0.730 & 0.466 \\
\hline PLANT & 18.537 & 12.601 & 1.471 & 0.143 \\
\hline PROCESS & -21.607 & 35.877 & -0.602 & 0.548 \\
\hline REC & 13.420 & 33.145 & 0.405 & 0.686 \\
\hline SEC & 48.427 & 68.493 & 0.707 & 0.480 \\
\hline SHOP & 15.983 & 4.786 & 3.340 & 0.001 \\
\hline STOR & 6.478 & 5.042 & 1.285 & 0.200 \\
\hline TRNG & 7.570 & 1.039 & 7.284 & 0.000 \\
\hline WHS & 3.902 & 2.900 & 1.346 & 0.180 \\
\hline \multicolumn{5}{|c|}{$\begin{array}{l}\text { Residual standard error: } 7.171 \text { on } 202 \text { degrees of freedom. } \\
\text { Multiple R-squared: } 0.8484 \text {. } \\
\text { F-statistic: } 47.09 \text { on } 24 \text { and } 202 \text { degrees of freedom; the p- }\end{array}$} \\
\hline
\end{tabular}


Table 4.4. Commercial Building Fossil Fuel Model Results

\begin{tabular}{|c|c|c|c|c|}
\hline & $\begin{array}{l}\text { EUI Value, } \\
\text { Btu/ft' }-\mathrm{yr}\end{array}$ & Standand Error & t Value & $\operatorname{Pr}(>|t|)$ \\
\hline ADMIN & 0.088 & 0.030 & 2.929 & 0.004 \\
\hline BRK & 0.078 & 0.039 & 1.974 & 0.051 \\
\hline CHAPEL & 0.877 & 1.313 & 0.668 & 0.505 \\
\hline CLINIC & 0.071 & 0.045 & 1.583 & 0.116 \\
\hline CLUB & -0.024 & 0.266 & -0.089 & 0.929 \\
\hline DGR & 0.164 & 0.179 & 0.916 & 0.361 \\
\hline DINING & 0.587 & 0.296 & 1.982 & 0.050 \\
\hline ELEC & -0.023 & 0.074 & -0.314 & 0.754 \\
\hline GRO & 0.218 & 0.313 & 0.696 & 0.488 \\
\hline HANGAR & 0.081 & 0.042 & 1.936 & 0.055 \\
\hline HOSP & 0.200 & 0.016 & 12.388 & 0.000 \\
\hline HOTEL & 0.128 & 0.044 & 2.920 & 0.004 \\
\hline LAB & 0.019 & 0.030 & 0.647 & 0.519 \\
\hline LAUNDRY & 1.680 & 1.332 & 1.261 & 0.210 \\
\hline MWR & -0.046 & 0.342 & -0.135 & 0.893 \\
\hline OTHER & 0.220 & 0.054 & 4.089 & 0.000 \\
\hline PLANT & -0.027 & 0.079 & -0.339 & 0.735 \\
\hline PROCESS & -0.027 & 0.057 & -0.466 & 0.642 \\
\hline REC & 0.136 & 0.165 & 0.820 & 0.413 \\
\hline SEC & -0.569 & 0.511 & -1.113 & 0.268 \\
\hline SHOP & 0.174 & 0.034 & 5.094 & 0.000 \\
\hline STOR & 0.011 & 0.037 & 0.306 & 0.760 \\
\hline TRNG & 0.010 & 0.011 & 0.909 & 0.365 \\
\hline WHS & 0.062 & 0.034 & 1.813 & 0.072 \\
\hline
\end{tabular}




\subsection{Linear-Regression Analysis of Metered Data}

The linear-regression analysis method used the metered data values that could be matched with a single building or group of identical buildings. For each data point, an EUI was calculated by dividing the metered energy consumption by the building area. For family housing and small training facilities, the energy use was divided by the summed area (either for housing or by building type for small installations). Both electricity and fossil fuel EUIs were calculated. The buildings at each installation were categorized according to their applicable Navy facility code (U.S. Navy 1993a). All EUI values were sorted by building type, and an average of each building type's EUIs was calculated.

The average building type EUIs for all installations were sorted by building type and weather parameters across all installations. Electric EUIs were sorted by $\operatorname{CDD}(65)$. Fossil fuel EUIs were sorted by HDD(65). EUI versus degree-day plots were made for each building type. Obvious outliers were removed, and a linear regression of the data was calculated. The slope of the linearregression line was the weather-dependent portion of the EUI. The vertical axis intercept was the constant, nonweather-dependent, portion of the EUI. The coefficient of determination $\left(r^{2}\right)$ of the regression was calculated to gauge the accuracy of the line fit. The following figures show this process and the range of available data. Figure 4.1 is an example of a "good" line fit, with only a few outliers removed. Figure 4.2 is an example of a "poor" line fit, with widely scattered data. Removing outliers in the second example did not affect the results and the $r^{2}$ value of 0.000 indicates a best achievable $r^{2}$ of less than one thousandth.

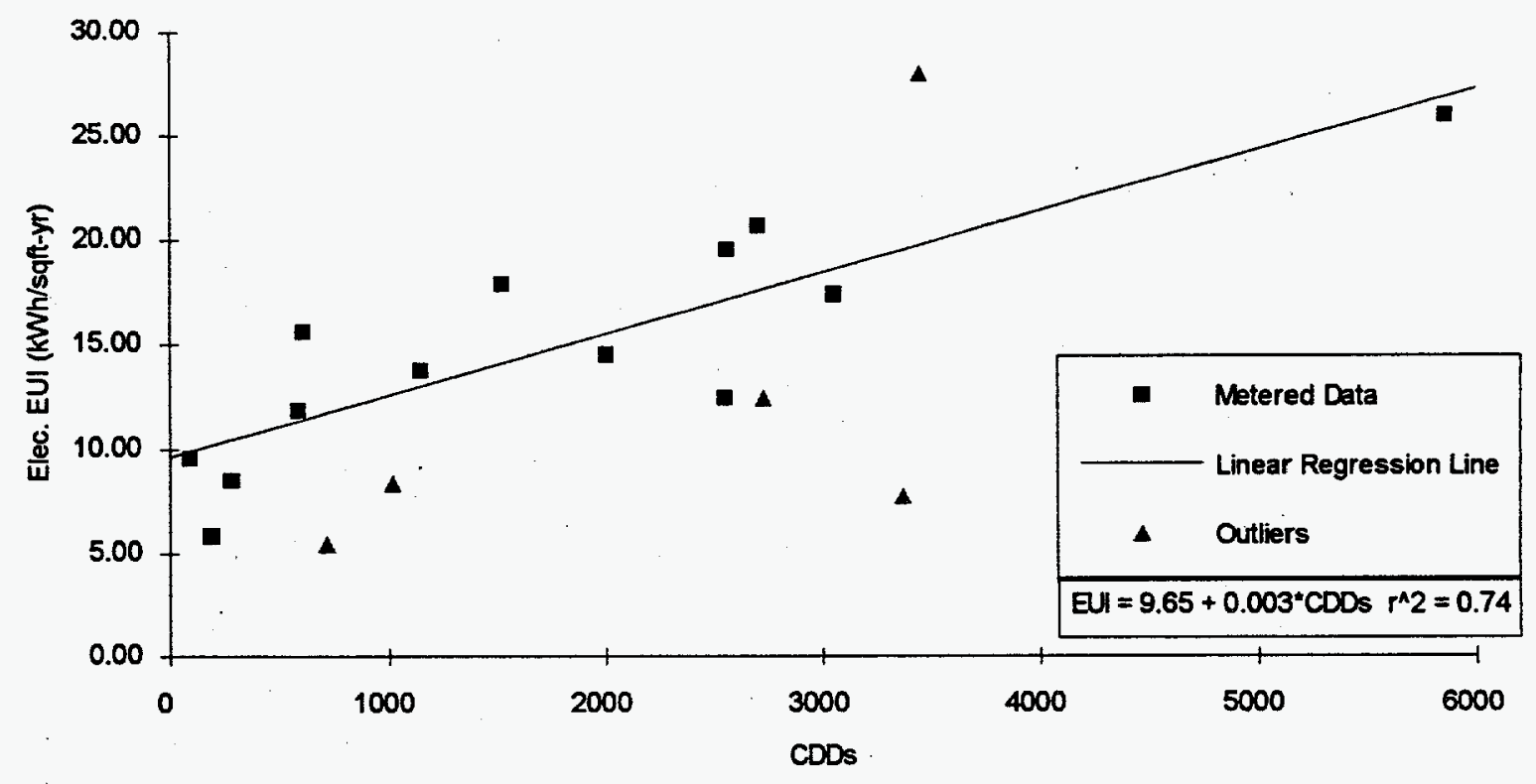

Figure 4.1. Linear Regression Used to Calculate Electric EUI Equation for Building Type ADMIN 


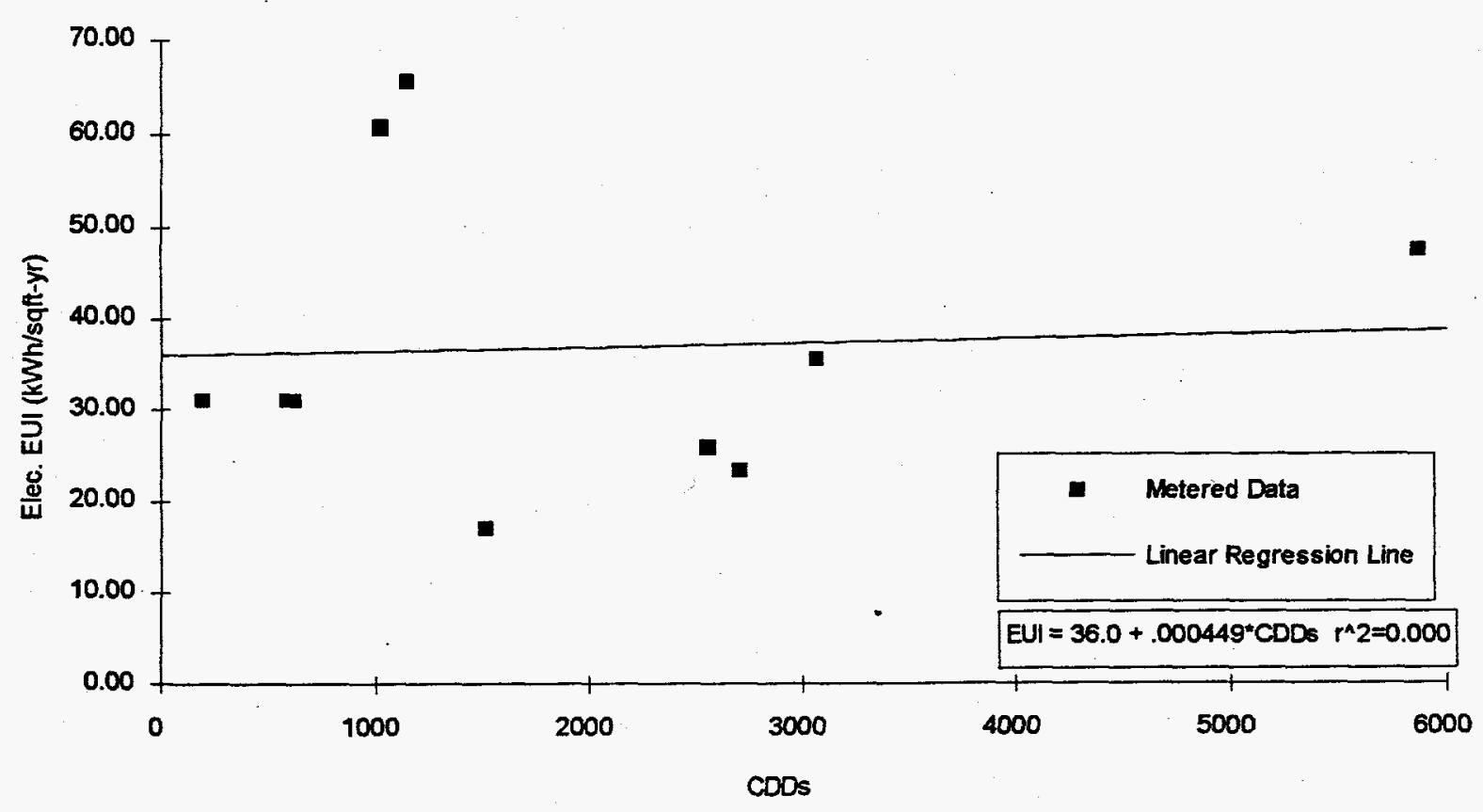

Figure 4.2. Linear Regression Used to Calculate Electric EUI Equation for Building Type ELEC

We then compared the slope and intercept to other EUI sources-principally other PNL studies. The data were manipulated in an attempt to maximize the $r^{2}$ and get EUI values that appeared reasonable compared to other EUIs developed in other similar studies. This process was done for each building type for both electricity and fossil fuel.

Insufficient individual building metered data existed to obtain satisfactory results for family housing. Therefore, the DEIS/UPA data were used. We calculated EUIs and plotted the data against several different weather parameters, including combinations of $\mathrm{HDD}(65)$ and WBH $>73^{\circ} \mathrm{F}$. The best fit for the electric data was a combination of $\mathrm{CDD}(65)$ and $\mathrm{WBH}>73^{\circ} \mathrm{F}$. These two parameters reflect the cooling energy from both sensible heat and humidity. Because this combination resulted in such a good fit for the housing data, we attempted the same combination for the other building types but no humidity effect was found. For fossil fuel, the best fit for family housing was based on HDD(65) only.

Several commercial building types did not have enough metered data to determine an EUI. These building types were usually special-use and/or process buildings where large industrial equipment loads are probably present. From the limited available data, it was impossible to quantify these buildings. We removed these buildings from the analysis because the EUIs would probably have been inaccurate. The only building type where an EUI was appropriate, but not calculated, was LAUNDRY. Only one metered data point was available and an EUI could not be properly calculated. 
Several additional factors are presented in the EUI table in the revised MO-303: electric domestic hot water (DHW), resistance heating, and heat pump heating. These factors were calculated by converting the DHW and heating factors, expressed in British thermal units (Btus), to kilowatthour (kWh) values and then applying an assumed fossil fuel equipment efficiency. Equation (4.5) shows the calculation for DHW and electric resistance heat. Equation (4.6) shows the calculation for heat pump heat.

Elec. DHW or Resistance Heat $=$ Fossil DHW or Heat $\times 0.29307 \times 0.75$

Elec. Heat Pump $=\frac{\text { Fossil Heat } \times 0.29307 \times 0.75}{2.5}$

where $0.29307=$ conversion from Btu to $\mathrm{kWh}$

$0.75=$ assumed efficiency of fossil fuel equipment

2.5 = assumed coefficient of performance (COP) of heat pump.

After determining estimates for all EUIs and other factors, a final testing process was applied to ensure the accuracy and applicability of the values. This process involved applying derived values at several Navy and other military installations to ensure their accuracy and applicability.

Initially, eight Navy installations were chosen representing various climate regions and base types (marine, air station, navy station, etc.). We summed the building areas $\left(\mathrm{ft}^{2}\right)$ on each installation by building type and performed a reconciliation similar to the process described in the revised MO-303. The appropriate EUI, weather, and other factors were applied to the building type square footage values. This calculated total energy use was compared to the reported total (installation billing total). Table 4.5 shows the results of the reconciliation process done for chosen Navy installations. This table compares the entire installation energy consumption to the energy consumption calculated using the EUI formulas.

In these comparisons, significant differences exist between the actual billed consumption and the calculated consumption. The primary difference is that total installation energy is compared to building-only energy (as calculated using the EUIs). Total energy consumption includes all additional items mentioned in the revised MO-303 that must be accounted for during a total reconciliation. The items include transmission and distribution (T\&D) losses, street lights, and water and sewer pumping. Another large source of error is the reported actual energy consumption. The amount and type of energy being used by the various tenant UICs on an installation are difficult to determine from the utility bills (UPA data) and the DEIS reports. However, in all but one of these comparisons, the estimated values using EUIs are consistently lower than the billing totals. The largest difference is for Portsmouth. Portsmouth is also the only compared installation with extremely high ship activity. This installation is also not included in the EUI values. This effect was expected because the nonbuilding portions of the total bills are not accounted for by the EUIs. 
Table 4.5. Comparison of Billed and Calculated Energy Consumption at Navy Installations

\begin{tabular}{|c|c|c|c|}
\hline & & $\begin{array}{l}\text { Electricity } \\
(\mathrm{kWh} / \mathrm{yr})\end{array}$ & $\begin{array}{l}\text { Fossil Fuel } \\
\text { (MBtu/yr) }\end{array}$ \\
\hline $\begin{array}{l}\text { Beaufort, SC } \\
\text { MCAS \& NH }\end{array}$ & $\begin{array}{r}\text { Calculated Building Total } \\
\text { Installation Billed Total } \\
\text { Bill/Calc.: }\end{array}$ & $\begin{array}{r}62,539,899 \\
63,863,337 \\
102.12 \%\end{array}$ & $\begin{array}{l}183,569 \\
214,489 \\
116.84 \%\end{array}$ \\
\hline $\begin{array}{l}\text { Corpus Christi, TX } \\
\text { NAS \& NH }\end{array}$ & $\begin{array}{r}\text { Calculated Building Total } \\
\text { Installation Billed Total } \\
\text { Bill/Calc.: }\end{array}$ & $\begin{array}{r}111,403,248 \\
112,687,600 \\
101.15 \%\end{array}$ & $\begin{array}{l}137,601 \\
318,378 \\
231.38 \%\end{array}$ \\
\hline $\begin{array}{l}\text { Great Lakes, IL } \\
\text { ALL PARTS }\end{array}$ & $\begin{array}{r}\text { Calculated Building Total } \\
\text { Installation Billed Total } \\
\text { Bill/Calc.: }\end{array}$ & $\begin{array}{r}118,702,780 \\
118,470,227 \\
99.80 \%\end{array}$ & $\begin{array}{r}1,143,651 \\
1,931,015 \\
168.85 \%\end{array}$ \\
\hline $\begin{array}{l}\text { Kittery, ME } \\
\text { PORTSMOUTH } \\
\text { NSY }\end{array}$ & $\begin{array}{r}\text { Calculated Building Total } \\
\text { Installation Billed Total } \\
\text { Bill/Calc.: }\end{array}$ & $\begin{array}{r}24,812,042 \\
78,781,000 \\
317.51 \%\end{array}$ & $\begin{array}{r}296,250 \\
1,000,120 \\
337.59 \%\end{array}$ \\
\hline $\begin{array}{l}\text { Willow Grove, PA } \\
\text { NAS }\end{array}$ & $\begin{array}{r}\text { Calculated Building Total } \\
\text { Installation Billed Total } \\
\text { Bill/Calc.: }\end{array}$ & $\begin{array}{r}11,295,775 \\
21,257,018 \\
188.19 \%\end{array}$ & $\begin{array}{r}65,299 \\
101,212 \\
155.00 \%\end{array}$ \\
\hline $\begin{array}{l}\text { Whidbey Island, WA } \\
\text { NAS }\end{array}$ & $\begin{array}{r}\text { Calculated Building Total } \\
\text { Installation Billed Total } \\
\text { Bill/Calc.: }\end{array}$ & $\begin{array}{r}45,526,306 \\
89,236,252 \\
196.01 \%\end{array}$ & $\begin{array}{l}371,716 \\
417,548 \\
112.33 \%\end{array}$ \\
\hline $\begin{array}{l}\text { Miramar, CA } \\
\text { NAS }\end{array}$ & $\begin{array}{r}\text { Calculated Building Total } \\
\text { Installation Billed Total } \\
\text { Bill/Calc.: }\end{array}$ & $\begin{array}{r}45,619,209 \\
54,311,581 \\
11.9 .05 \%\end{array}$ & $\begin{array}{l}138,970 \\
285,880 \\
205.71 \%\end{array}$ \\
\hline $\begin{array}{l}\text { Camp Lejeune, NC } \\
\mathrm{MCB}\end{array}$ & $\begin{array}{r}\text { Calculated Building Total } \\
\text { Installation Billed Total } \\
\text { Bill/Calc.: }\end{array}$ & $\begin{array}{r}240,780,564 \\
365,548,000 \\
151.82 \%\end{array}$ & $\begin{array}{r}1,122,452 \\
1,619,113 \\
144.25 \%\end{array}$ \\
\hline
\end{tabular}

To refine the testing process and better identify actual estimate differences, we performed similar reconciliations on six Army and Air Force installations (Dixon et al.. 1992; Dixon et al. 1993; Halverson et al. 1993; Keller et al. 1993a; Keller et al. 1993b; Richman et al. 1994). These installations were chosen because all nonbuilding loads and the total building consumption were well documented. Each installation was included in individual case studies where all installation energy was accounted for and allocated. Although not all energy was utility metered at these installations, much time and effort were expended in accurately assessing the building and nonbuilding energy use with additional long- and short-term energy monitoring of facilities and processes. The detail provided by these case studies is a good basis for more accurately assessing building-only energy use. The differences between similar types of Navy and Army/Air Force buildings are considered 
negligible. As before, the calculated building energy use based on the derived EUIs was compared to the building energy-use totals for each installation. Wherever significant differences were noted, adjustments were made to the EUI and other factor values and the comparison was recalculated. Table 4.6 presents the final (adjusted) comparisons of building-only energy for these installations.

In each of these comparisons, the calculated versus billed values are relatively close. Most comparisons are generally within plus or minus $20 \%$, which is reasonably accurate considering the magnitude of the estimate and the many possible variables.

Table 4.7 presents the results of the EUI calculation process (after adjustments) along with the $\mathrm{r}^{2}$ and number of data points for each regression. The units of the heating and cooling factors were changed to watt-hours (Whs) and Btus for ease of calculation in the revised MO-303.

Table 4.6. Comparison of Billed and Calculated Building-Only Energy Consumption

\begin{tabular}{|c|c|c|c|}
\hline & & $\begin{array}{c}\text { Electricity } \\
(\mathrm{kWh} / \mathrm{yr})\end{array}$ & $\begin{array}{c}\text { Fossil Fuel } \\
\text { (MBtu/yr) }\end{array}$ \\
\hline Fort Stewart & $\begin{array}{r}\text { Calculated Building Total: } \\
\text { Billed Building Total: } \\
\text { Bill/Calc.: }\end{array}$ & $\begin{array}{r}130,852,498 \\
103,861,000 \\
79.37 \%\end{array}$ & $\begin{array}{l}315,173 \\
427,365 \\
135.60 \%\end{array}$ \\
\hline Robins AFB & $\begin{array}{r}\text { Calculated Building Total: } \\
\text { Billed Building Total: } \\
\text { Bill/Calc.: }\end{array}$ & $\begin{array}{r}179,983,034 \\
209,516,801 \\
116.41 \%\end{array}$ & $\begin{array}{l}430,778 \\
458,666 \\
106.47 \%\end{array}$ \\
\hline Vandenberg AFB & $\begin{array}{r}\text { Calculated Building Total: } \\
\text { Billed Building Total: } \\
\text { Bill/Calc.: }\end{array}$ & $\begin{array}{r}164,231,208 \\
133,690,523 \\
81.40 \%\end{array}$ & $\begin{array}{l}545,886 \\
664,887 \\
121.80 \%\end{array}$ \\
\hline Griffiss AFB & $\begin{array}{r}\text { Calculated Building Total: } \\
\text { Billed Building Total: } \\
\text { Bill/Calc.: }\end{array}$ & $\begin{array}{r}71,301,582 \\
72,944,217 \\
102.30 \%\end{array}$ & $\begin{array}{l}497,802 \\
542,416 \\
108.96 \%\end{array}$ \\
\hline Fort Drum & $\begin{array}{r}\text { Calculated Building Total: } \\
\text { Billed Building Total: } \\
\text { Bill/Calc.: }\end{array}$ & $\begin{array}{r}96,098,383 \\
95,377,928 \\
99.25 \%\end{array}$ & $\begin{array}{r}1,153,644 \\
1,239,653 \\
107.46 \% \\
\end{array}$ \\
\hline Fort Irwin & $\begin{array}{r}\text { Calculated Building Total: } \\
\text { Billed Building Total: } \\
\text { Bill/Calc.: }\end{array}$ & $\begin{array}{r}67,611,087 \\
58,106,000 \\
85.94 \%\end{array}$ & $\begin{array}{r}258,190 \\
213,874 \\
82.84 \%\end{array}$ \\
\hline
\end{tabular}


Table 4.7. Results of the Linear-Regression Calculations

\begin{tabular}{|c|c|c|c|c|c|c|c|c|c|}
\hline \multirow[b]{3}{*}{$\begin{array}{c}\text { Building } \\
\text { Types }\end{array}$} & \multicolumn{5}{|c|}{ Electric } & \multicolumn{4}{|c|}{ Nonelectric } \\
\hline & \multicolumn{3}{|c|}{ Cooling } & \multirow[b]{2}{*}{$r^{2}$} & \multirow[b]{2}{*}{$\begin{array}{c}\text { Number } \\
\text { of } \\
\text { Points }\end{array}$} & \multirow[b]{2}{*}{$\begin{array}{c}\text { DHW } \\
\text { EUI, } \\
\mathrm{kBtu} / \\
\mathrm{ft}^{2}-\mathrm{yr}\end{array}$} & \multirow{2}{*}{$\begin{array}{l}\text { Heating } \\
\text { HDD(65) } \\
\text { Factor, } \\
\text { Btu/ft }{ }^{2}- \\
\text { HDD }(65)\end{array}$} & \multirow[b]{2}{*}{$r^{2}$} & \multirow[b]{2}{*}{$\begin{array}{c}\text { Number } \\
\text { of } \\
\text { Points }\end{array}$} \\
\hline & $\begin{array}{l}\text { Misc. } \\
\text { EUI, } \\
\text { kWh/ } \\
\mathrm{ft}^{2}-\mathrm{yr}\end{array}$ & $\begin{array}{c}\mathrm{CDD}(65) \\
\text { Factor, } \\
\mathrm{Wh} / \mathrm{ft}^{2}- \\
\mathrm{CDD}(65)\end{array}$ & $\begin{array}{c}\text { WBH } \\
\geq 73^{\circ} \mathrm{F} \\
\text { Factor, } \\
\text { Wh/ } / \mathrm{ft}^{2}- \\
\text { WBH(73) }\end{array}$ & & & & & & \\
\hline ADMIN & 9.65 & 2.93 & 0 & 0.74 & 18 & 13.4 & 8.51 & 0.75 & 12 \\
\hline BRK & 4.88 & 3.00 & 0 & 0.75 & 10 & 32.7 & 4.81 & 1.00 & 6 \\
\hline CHAPEL & 4.38 & 1.46 & 0 & 0.99 & 4 & 0.468 & 12.7 & 1.00 & 2 \\
\hline CLINIC & 11.76 & 4.16 & 0 & 0.75 & 9 & 37.8 & 13.2 & 0.12 & 9 \\
\hline CLUB & 11.6 & 4.65 & 0 & 0.69 & 9 & 32.4 & 4.84 & 0.64 & 7 \\
\hline DGR & 13.6 & 4.84 & 0 & 0.61 & 13 & 11.9 & 5.09 & 0.65 & 8 \\
\hline DINING & 24.6 & 1.99 & 0 & 0.34 & 7 & 32.4 & 4.84 & 0.64 & 7 \\
\hline ELEC & 36.0 & 0.449 & 0 & 0.00 & 10 & 10.5 & 14.5 & 0.65 & 7 \\
\hline FH & 5.84 & 0.539 & 1.74 & 0.57 & 94 & 17.4 & 8.83 & 0.43 & 99 \\
\hline GRO & 32.9 & 6.31 & 0 & 0.54 & 7 & 13.1 & 5.13 & 0.22 & 6 \\
\hline HANGAR & 9.69 & 3.10 & 0 & 1.00 & 6 & 7.31 & 8.83 & 0.53 & 55 \\
\hline HOSP & 17.1 & 11.9 & 0 & 0.79 & 7 & 37.8 & 13.2 & 0.12 & 9 \\
\hline HOTEL & 10.1 & 4.20 & 0 & 0.76 & 8 & 33.0 & 4.65 & 0.99 & 8 \\
\hline LAB & 16.6 & 2.14 & 0 & 0.66 & 10 & 17.0 & 11.4 & 0.01 & 7 \\
\hline MWR & 10.3 & 2.92 & 0 & 0.80 & 9 & 12.6 & 16.7 & 0.92 & 6 \\
\hline OTHER & 7.65 & 3.54 & 0 & 0.49 & 5 & 25.0 & 13.8 & 1.00 & 4 \\
\hline REC & 10.9 & 1.70 & 0 & 0.30 & 11 & 16.0 & 11.4 & 1.00 & 6 \\
\hline SEC & 13.4 & 2.44 & 0 & 0.49 & 9 & 14.6 & 12.1 & 0.87 & 7 \\
\hline SHOP & 4.76 & 1.59 & 0 & 0.32 & 72 & 7.31 & 8.83 & 0.53 & 55 \\
\hline STOR & 1.42 & 1.52 & 0 & 0.84 & 26 & 3.48 & 8.38 & 0.51 & 26 \\
\hline TRNG & 2.83 & 1.48 & 0 & 0.44 & 145 & 6.52 & 7.48 & 0.40 & 116 \\
\hline WHS & 4.29 & 1.60 & 0 & 0.51 & 17 & 3.48 & 8.38 & 0.51 & 26 \\
\hline
\end{tabular}




\subsection{Ship Energy-Use Estimation Development}

Because ship energy use is a large portion of total energy consumption at many installations, an effective and accurate method of estimating ship energy use is needed. Unfortunately, very little actual ship metered data were received in the data collection effort. Usually, the collected data was at a pier level without sufficient ship docking information to derive actual consumption values. Early efforts to collect additional ship data and ship docking information were generally unsuccessful because most ship data used at installations is estimated. The large variety of ship types and classes also made available data less effective. Because metered data were not available to estimate energyuse values, the best source of consistent data was the data found in MH/1025-2 (DOD 1988).

The data in MH/1025-2 are not consistently current and are based solely on design load conditions. However, the data are considered consistent among themselves and therefore can provide reasonable relative values.

The revised MO-303 discusses reconciling pier data to derive effective ship metered data as a way to use design load data to prorate actual ship energy use. This process is considered the best available method for estimating ship energy consumption except for installing more metering equipment. 


\subsection{Changes to 1972 Version of $\mathrm{MO}-303$}

The changes to each chapter, section, figure, and table of the 1972 version of MO-303, as part of the revision process, are shown below (U.S. Navy 1972b).

Chapter/Section/Figure/Table

Chapter 1

Chapter 2

Sections 2.1, 2.2

Section 2.2.1

Section 2.2 .2

Sections 2.2.3, 2.2.4

Section 2.2.5

Section 2.2.6

Section 2.2.7

Section 2.2.8

Section 2.3

Section 2.4

Figure 2.1

Table 2.1

Table 2.2

Table 2.3

Table 2.4

Table 2.5

Table 2.6

Table 2.7

\section{Description of Change}

Rewritten as new introduction.

See individual parts below.

Included in introduction.

Eliminated-does not provide anything to the estimation processes.

Eliminated except for part 5 on exterior lighting, which was rewritten and included in new Section 2.5.

Rewritten and incorporated into new Sections 2.2 and 2.5.

Eliminated.

Eliminated.

Mostly eliminated-some information used in new Section 2.2.

Rewritten and included in new Section 3.

Rewritten and included in new Section 2.2.

Rewritten and included in new Sections 2.2, 2.3, and 2.4.

Eliminated.

Table eliminated, but real property data source referenced and discussed in new Sections 2.1 and 2.2.

Eliminated.

Replaced with new Table B.1.

Eliminated.

Eliminated.

Replaced with new Table 2.5.

Incorporated into new Table 2.7. 
Chapter/Section/Figure/Table

Tables 2.8, 2.9

Table 2.10

Tables 2.11, 2.12, 2.13, 2.19

Figures 2.2, 2.3, 2.4, 2.5, 2.6

Tables 2.20, 2.21

Chapter 3

Chapter 4

Sections $4.1-4.5$

Section 4.6

Section 4.7

Sections 4.8 and 4.9

Sections 4.10 and 4.11

Tables $4.1-4.5,4.26,4.27$

Tables 4.6, 4.7, 4.9, 4.10, 4.15, 4.16

Figures 4.1, 4.2

Table 4.8

Table 4.11

Tables $4.12-4.27$

Chapter 5

Tables $5.1-5.8$

Chapter 6

\section{Description of Change}

Eliminated.

Eliminated.

Either eliminated or included in new Table 2.7.

Eliminated.

Replaced with new Tables B.2 and B.3.

Not in project scope.

See individual parts below.

Either eliminated or rewritten and incorporated into new Sections 2.2 and 2.3.

Incorporated into new Section 2.4.

Eliminated.

Either eliminated or rewritten and incorporated in new Sections 2.2 and 2.3 .

Eliminated.

Eliminated or incorporated into new Tables 2.1 through 2.7 .

Eliminated.

Eliminated.

Replaced with new Table B.1.

Replaced with new Tables B.2 and B.3.

Eliminated or incorporated into new Tables 2.1 through 2.7.

All sections in this chapter are incorporated appropriately into the new Section 2.2.

Eliminated.

All sections in this chapter (with the exception of Section 6.3 "Potable Water Estimate") are incorporated into new Sections 2.2 through 3 . 


\subsection{References}

Dixon, D. R., P. R. Armstrong, J. R. Broderick, K. K. Daellenbach, F. V. DiMassa, J. M. Keller, E. E. Richman, G. P. Sullivan, and R. R. Wahlstrom. 1992. Fort Drum Integrated Resource Assessment, Volume 2: Baseline Detail. PNL-8424 Vol. 2, Pacific Northwest Laboratory, Richland, Washington.

Dixon, D. R., P. R. Armstrong, and J. M. Keller. 1993. Griffiss Air Force Base Integrated Resource Assessment, Volume 2: Baseline Detail. PNL-8545 Vol. 2, Pacific Northwest Laboratory, Richland, Washington.

Halverson, M. A., E. E. Richman, J. E. Dagle, B. J. Hickman, K. K. Daellenbach, and G. P. Sullivan. 1993. Vandenberg Air Force Base Integrated Resource Assessment, Volume 2: Baseline Detail. PNL-8730 Vol. 2, Pacific Northwest Laboratory, Richland, Washington.

Keller, J. M., G. P. Sullivan, R. R. Wahlstrom, and L. L. Larson. 1993a. Fort Stewart Integrated Resource Assessment, Volume 2: Baseline Detail. PNL-8771 Vol. 2, Pacific Northwest Laboratory, Richland, Washington.

Keller, J. M., G. P. Sullivan, R. R. Wahlstrom, and L. L. Larson. 1993b. Robins Air Force Base Integrated Resource Assessment, Volume 2: Baseline Detail. PNL-8809 Vol. 2, Pacific Northwest Laboratory, Richland, Washington.

Richman, E. E., J. M. Keller, A. L. Dittmer, and D. L. Hadley. 1994. Fort Irwin Integrated Resource Assessment, Volume 2: Baseline Detail. PNL-9065 Vol. 2, Pacific Northwest Laboratory, Richland, Washington.

Secrest, T. J., J. W. Currie, J. G. DeSteese, J. A. Dirks, T. J. Marseille, G. B. Parker, E. E. Richman, and S. A. Shankle. 1991. Fort Lewis Electric Energy Baseline and Efficiency Resource Assessment. PNL-7763, Pacific Northwest Laboratory, Richland, Washington.

U.S. Department of Defense (DOD). 1988. Military Handbook: Dockside Utilities for Ship Service. MIL-HDBK-1025-2, U.S. Government Printing Office, Washington D.C.

U.S. Federal Energy Management Program (FEMP). 1993. FEDS Users Guide: Level-1 Building Version, Federal Energy Decision Screening Software - Release 1.2. U.S. Department of Energy, Washington, D.C.

U.S. Navy. 1972a. Activity Conservation Techniques. NAVFAC MO-305, Naval Facilities Engineering Command, Washington D.C.

U.S. Navy. 1972b. Utilities Target Manual. NAVFAC MO-303, Naval Facilities Engineering Command, Washington D.C.

U.S. Navy. 1978. Engineering Weather Data for Design and Construction. NACFAC P-89, U.S. Government Printing Office, Washington D.C. 
U.S. Navy. 1991. Electric Power Distribution Systems Operations. NAVFAC MO-201, Naval Facilities Engineering Command, Washington D.C.

U.S. Navy. 1992. Navy Facilities Assets Data Base Management System Procedures Manual. NAVFAC P-78, Naval Facilities Engineering Command, Washington D.C.

U.S. Navy. 1993a. Facility Category Codes. FACSO RPT 11016/R8042R01, Naval Facilities Engineering Command, Washington D.C.

U.S. Navy. 1993b. Navy Real Property - Class 1 and 2: Detail. FACSO RPT 11016/R4640R01, Naval Facilities Engineering Command, Washington D.C. 


\section{Distribution}

No. of

Copies

Offsite

12 DOE/Office of Scientific and Technical Information

J. L. Heller

Naval Facilities Engineering Service Center 1001 Lyons Street Suite 1

Port Hueneme, CA 93043-4340

D. Rydberg

Naval Facilities Engineering Service Center 1001 Lyons Street Suite 1

Port Hueneme, CA 93043-4340

J. M. Keller

Interwest Consulting Engineers

4141 South Highland Drive \#202

Salt Lake City, Utah 84124
No. of

Copies

Onsite

21 Pacific Northwest Laboratory

C. A. Anderson $\quad$ K5-20

D. M. Carroll K5-08

A. L. Dittmer K5-08

E. E. Richman (10) K5-08

W. F. Sandusky K5-08

A. G. Wood K5-06

Publishing Coordination K1-06

Technical Report Files (5)

Distr. 1 